\title{
Assessment of the Effects of Temperature, Precipitation and Altitude on Greenhouse Gas Emission from Soils in Lagos Metropolis
}

\author{
Rose Alani ${ }^{1}$, Shakurideen Odunuga ${ }^{2}$, Nkenie Andrew-Essien'1, Youpele Appia ${ }^{3}$, \\ Kolawole Muyiolu ${ }^{4}$ \\ ${ }^{1}$ Department of Chemistry, University of Lagos, Lagos, Nigeria \\ ${ }^{2}$ Department of Geography, University of Lagos, Lagos, Nigeria \\ ${ }^{3}$ Nigeria Institute of Oceanography and Marine Studies, Lagos, Nigeria \\ ${ }^{4}$ Nigeria Meteorological Agency (NIMET), Lagos, Nigeria \\ Email: ralani@unilag.edu.ng
}

How to cite this paper: Alani, R., Odunuga, S., Andrew-Essien, N., Appia, Y. and Muyiolu, K. (2017) Assessment of the Effects of Temperature, Precipitation and Altitude on Greenhouse Gas Emission from Soils in Lagos Metropolis. Journal of Environmental Protection, 8, 98-107.

http://dx.doi.org/10.4236/jep.2017.81008

Received: July 7, 2016

Accepted: January 22, 2017

Published: January 25, 2017

Copyright $\odot 2017$ by authors and Scientific Research Publishing Inc. This work is licensed under the Creative Commons Attribution International License (CC BY 4.0).

http://creativecommons.org/licenses/by/4.0/

\begin{abstract}
Significant pool of carbon is present in the biosphere as soil organic carbon (SOC). More carbon is stored in the soils which include peatlands, wetlands and permafrost than is present in the atmosphere. There are still controversies regarding the effects of climate change on global soil carbon stocks. This study seeks to: assess the effect of altitude, temperature and precipitation on the greenhouse gas emission from soil; and to examine the correlation between soil organic carbon and soil texture. With a total of 81 samples collected at 3 different depths $(0-10 \mathrm{~cm}, 10-20 \mathrm{~cm}, 20-30 \mathrm{~cm})$ from 27 locations in different regions of Lagos, the relation of soil organic carbon concentration to climate was investigated. Samples taken were analyzed for soil organic matter, soil organic carbon (SOC), and percentage of silt/clay/sand. The amount of carbon dioxide released was calculated. Temperature, precipitation and altitude were also taken into consideration. From the 27 locations topsoil had 8 locations of highest SOC contents; middle soil had 2 locations of highest SOC contents while bottom soil had 17 locations of highest SOC contents. SOC contents of top soil were linked with soil texture, vegetation type, temperature, precipitation, and altitude. The study showed that SOC increased with decrease in temperature, decrease in precipitation, and increase in altitude. Forest, shrubs and grassland types of vegetation, as well as soil depths also favour SOC contents. The study also showed that increase in temperature and altitude favours greenhouse gas emission from the soil. From our findings, SOC and climate change are greatly linked.
\end{abstract}




\section{Keywords}

Climate Change, Soil Organic Carbon, Greenhouse Gas Emission, Lagos

\section{Introduction}

Soil is an important environmental medium that has so much influence on life on earth. When changes occur in soils as a result of pollution from natural or anthropogenic activities, all other environmental media become affected and subsequently all forms of life is also affected. This paper shall focus on soil carbon and how it is connected to the climate change phenomenon and soil texture.

The bulk of carbon on land is locked up in soils and in trees as reservoirs. Soil is the largest pool of terrestrial organic carbon in the biosphere, storing more carbon than is contained in plants and the atmosphere combined [1]. Minor changes in the balance between belowground carbon storage and release could have major impacts on greenhouse gases. The patterns and controls of soil organic carbon (SOC) storage are critical for our understanding of the biosphere, given the importance of SOC for ecosystem processes and the feedback of this pool to atmospheric composition and the rate of climate change [2] [3] [4].

Because soil gas release is temperature sensitive, global warming will probably create a positive feedback, causing soils to release more greenhouse gases that will further exacerbate the problem. Since the industrial revolution, human activities, including the burning of fossil fuels and land use have contributed to a great increase in the amount of carbon dioxide $\left(\mathrm{CO}_{2}\right)$, atmospheric methane, carbon monoxide (CO) and other Green House Gases in the atmosphere [5] [6]. Over the past decades, many scientists have argued that this human induced change in atmosphere is to a large degree responsible for global climate change and variability [7]. Global warming changes the earth's atmospheric circulation and is linked to changes in patterns of precipitation and the frequency and intensity of extreme climate events [8] [9] [10].

Lagos has consistently high temperatures, with the mean monthly maximum temperature of about 30 degrees Celsius [11]. Lagos experiences the highest temperatures in November to December and February to March, while the lowest temperatures occur in June to July, which coincides with the middle of the first period of peak rainfall. Floods usually occur during these periods of peak rainfall. The Lagos soils possibly provide a significant source of $\mathrm{CO}_{2}$ due to high human activities such as burning of fossil fuels, agriculture, and land use, to the atmosphere. Lagos is endowed with very little arable land. Altogether, four soil groups are identifiable. On the western half of the coastal margin, juvenile soils on recent windborne sands occur. The rest of the coastal area towards the east is covered also by juvenile soils on fluviomarine alluvium (mangrove swamp). Thirdly, a narrow and rather discontinuous band of mineral and/or organic hydromorphic soils occurs in the middle and north eastern sections of the state. The fourth group, occurring in two rather tiny and discontinuous patches along 
the northern limits of the state, consists dominantly of red ferallitic soils on loose sandy sediments (www.onlinenigeria.com). Formation process, geographical distribution and principal properties of the soil sample were mainly controlled by climate and vegetation regimes along horizontal and vertical dimension [12]. It has been estimated that up to $39 \%$ of organic carbon in cultivated surface soils has been lost between 1860 and 1990 [13].

The impacts of climate change are being felt in every sector of Lagos State, including agriculture and food security; water resources; wetlands and freshwater ecosystems; coastal zone and marine eco-systems; land use, forestry and biodiversity; energy; transportation; industry and commerce; financial services; human settlements and health; and disaster management. The possibility that climate change is being reinforced by increased carbon dioxide emissions from soils owing to rising temperature is the subject of a continuing debate [14]. Our study aims at contributing to this debate. The study also aims at examining the climate change situation in Nigeria by assessing the link between SOC and Mean Annual Temperature (MAT), Mean Annual Precipitation (MAP), altitude, soil texture and vegetation types. There is a link between SOC, climate change and greenhouse gas emission. Climate is the most important factor regulating soil organic matter [15]. The link between greenhouse gas emission and climate change will also be assessed in this study.

\section{Methods}

Samples were collected from nine (9) grids which covered eight (8) local government areas (Ikeja, Eti Osa, Lagos Island, Surulere, Kosofe, Isolo, Ikorodu and Isolo). From each grid three (3) sample locations were selected to make a total of twenty seven (27) sample locations between longitude $3^{\circ} 16^{\prime} 0^{\prime \prime} \mathrm{E}-3^{\circ} 36^{\prime} \mathrm{O}^{\prime \prime} \mathrm{E}$ and latitude $6^{\circ} 24^{\prime} 0^{\prime \prime} \mathrm{N}-6^{\circ} 44^{\prime} 0^{\prime \prime} \mathrm{N}$, as shown in Figure 1.

From each location, 3 core samples comprising top soil $(0-10 \mathrm{~cm})$, subsoil soil $(10-20 \mathrm{~cm})$ and bottom soil $(20 \mathrm{~cm}-30 \mathrm{~cm})$ were taken using a soil auger, to make a total of eighty one (81) samples for this study. Annual mean temperature, annual mean precipitation readings and altitudes of the sample locations were obtained from the Nigeria Meteorological Agency (NIMET), Lagos, Nigeria, as shown in Table 1.

The soil samples were air dried at ambient temperature for a few days and sieved through a $2-\mathrm{mm}$ stainless steel sieve prior to analysis. The soil moisture content was determined by gravimetric method at $105^{\circ} \mathrm{C}$. Walkey-Black method was used in the determination of organic carbon content (TOC). This involved a wet combustion (oxidation) of the organic matter in a known mass of samples with a mixture of potassium dichromate sulphuric acid. Up to $2.0 \mathrm{~g}$ of sample was used for light colored soils (indicating poor organic carbon content) and 0.1 $\mathrm{g}$ was used for dark colored soil (indicating very rich in organic carbon). After the reaction, the residual (excess) potassium dichromate was titrated against standard ferrous solution using ferroin indicator. From the result the TOC was calculated. The Walkley-Black wet oxidation technique (used in this research 


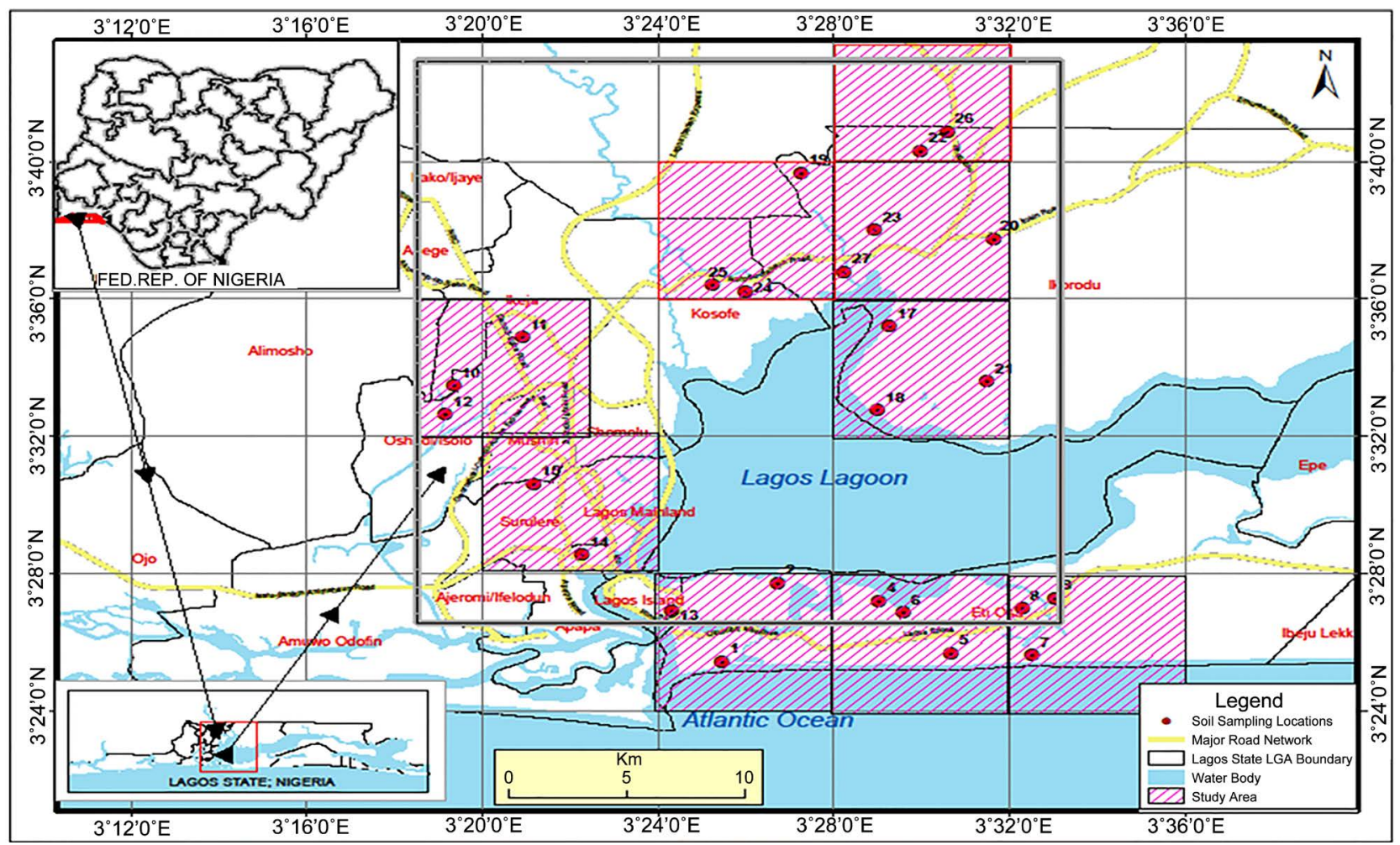

Figure 1. Map of Lagos showing the study area and sample locations.

project) only measures $70 \%-90 \%$ of the total SOC, depending on soil type [16]. The amount of SOC that is stored in a soil was therefore calculated using the equation [17]:

SOC $(\mathrm{t} / \mathrm{ha})=$ depth $(\mathrm{cm}) \times$ bulk density $\left(\mathrm{g} / \mathrm{cm}^{3}\right) \times$ organic carbon content $(\%)$ SOC was converted to Carbon Dioxide using a conversion factor of 3.67. According to [12], when SOC is sequestered from, or mineralised to, atmospheric $\mathrm{CO}_{2}$, a conversion factor of 3.67 is used to determine the change in mass due to the loss or gain of oxygen molecules. 1 tonne of soil $\mathrm{C}=3.67$ tonnes of $\mathrm{CO}_{2}$ (sequestered or emitted based on the ratio of the molecular weights of carbon (12) and carbon dioxide (44), i.e. $44 / 12=3.67$.

Granulometric analysis of the soil was carried out to also determine the particle size distribution using sieves of various mesh sizes and gravity sedimentation, in a measure of cylinder. $100 \mathrm{~g}$ of soil was used. The particle held by each sieve sizes was weighed and expressed as a percentage of overall mass of each soil used in the experiment. The particles were differentiated into sand, gravel, silt and clay according to the mesh size of the sieves. Sieve sizes used were 3000 (control), 2400 microns, 1200 microns, 600 microns, 420 microns, 300 microns, 210 microns, 150 microns and 75 microns.

\section{Results and Discussion}

Our capacity to predict and assess the consequences of climate and land cover change depends partly on the clear description of soil organic carbon (SOC) distributions and the controls of SOC inputs and outputs. 
Table 1. Mean annual temperature (MAT), mean annual precipitation (MAP) and altitudes of sample locations.

\begin{tabular}{|c|c|c|c|c|c|c|}
\hline Sample & Location & Latitude & Longitude & $\operatorname{MAT}\left({ }^{\circ} \mathrm{C}\right)$ & MAP (mm) & Altitude (m) \\
\hline 1 & Victoria Island, Eti Osa LGA & $\mathrm{N}: 06^{\circ} 25^{\prime} 25.083^{\prime \prime}$ & E: $03^{\circ} 25^{\prime} 00.7^{\prime \prime}$ & 27.9 & 1828.80 & 8 \\
\hline 2 & Ikoyi, Eti Osa LGA & $\mathrm{N}: 06^{\circ} 25^{\prime} 27.795^{\prime \prime}$ & E: $03^{\circ} 26^{\prime} 35.627^{\prime \prime}$ & 27.9 & 1828.80 & 0 \\
\hline 3 & Oniru, Eti Osa LGA & $\mathrm{N}: 06^{\circ} 25^{\prime} 27.9^{\prime \prime}$ & E: $03^{\circ} 26^{\prime} 35.9^{\prime \prime}$ & 27.9 & 1828.80 & 5 \\
\hline 4 & Lekki Phase 1, Eti-Osa LGA & $\mathrm{N}: 06^{\circ} 27^{\prime} 11.8^{\prime \prime}$ & E: $03^{\circ} 29^{\prime} 01.0^{\prime \prime}$ & 27.9 & 1828.80 & 6 \\
\hline 5 & Maiyegun, Eti-Osa LGA & $\mathrm{N}: 06^{\circ} 25^{\prime} 40.4^{\prime \prime}$ & E: $03^{\circ} 30^{\prime} 39.6^{\prime \prime}$ & 27.9 & 1828.80 & 0 \\
\hline 6 & Ikate, Eti-Osa LGA & $\mathrm{N}: 06^{\circ} 26^{\prime} 50.5^{\prime \prime}$ & E: $03^{\circ} 29^{\prime} 34.0^{\prime \prime}$ & 27.9 & 1828.80 & 9 \\
\hline 7 & Okun-Alfa, Eti-Osa LGA & $\mathrm{N}: 06^{\circ} 25^{\prime} 41.7^{\prime \prime}$ & E: $03^{\circ} 31^{\prime} 42.4^{\prime \prime}$ & 27.9 & 1828.80 & 10 \\
\hline 8 & Ajiran, Eti-Osa LGA & $\mathrm{N}: 06^{\circ} 27^{\prime} 00.8^{\prime \prime}$ & E: $03^{\circ} 31^{\prime} 50.9$ & 27.9 & 1828.80 & 14 \\
\hline 9 & Ikota, Eti-Osa LGA & $\mathrm{N}: 06^{\circ} 226^{\prime} 56.2^{\prime \prime}$ & E: $03^{\circ} 32^{\prime} 45.7^{\prime \prime}$ & 27.9 & 1828.80 & 12 \\
\hline 10 & Airport Road, Ikeja LGA & N: $06^{\circ} 33^{\prime} 27.1^{\prime \prime}$ & E: $03^{\circ} 19^{\prime} 20.8^{\prime \prime}$ & 25.8 & 1473.20 & 26 \\
\hline 11 & Ikeja GRA, Ikeja LGA & $\mathrm{N}: 06^{\circ} 34^{\prime} 51.7^{\prime \prime}$ & E: $03^{\circ} 20^{\prime} 54^{\prime} 6^{\prime \prime}$ & 25.8 & 1473.20 & 46 \\
\hline 12 & Ajao Estate, Isolo LGA & $\mathrm{N}: 06^{\circ} 32^{\prime} 36.9^{\prime \prime}$ & E: $03^{\circ} 19^{\prime} 09.2^{\prime \prime}$ & 25.8 & 1473.20 & 20 \\
\hline 13 & Onikan, Lagos-Island LGA & $\mathrm{N}: 06^{\circ} 26^{\prime} 52.5^{\prime \prime}$ & E: $03^{\circ} 23^{\prime} 56.2^{\prime \prime}$ & 27.9 & 1828.80 & 20 \\
\hline 14 & $\begin{array}{l}\text { National House Theater, } \\
\text { Iganmu LGA }\end{array}$ & $\mathrm{N}: 06^{\circ} 28^{\prime} 31.8^{\prime \prime}$ & E: $03^{\circ} 22^{\prime} 15.6^{\prime \prime}$ & 25.2 & 1591.45 & 7 \\
\hline 15 & $\begin{array}{l}\text { Adeniran Ogunsanya } \\
\text { Surulere LGA }\end{array}$ & $\mathrm{N}: 06^{\circ} 30^{\prime} 36.0^{\prime \prime}$ & E: $03^{\circ} 21^{\prime} 09.9^{\prime \prime}$ & 25.2 & 1591.45 & 8 \\
\hline 16 & Ologede, Ikorodu LGA & $\mathrm{N}: 06^{\circ} 37^{\prime} 59.79^{\prime \prime}$ & E: $03^{\circ} 28^{\prime} 55.61^{\prime \prime}$ & 24.8 & 1541.81 & 10 \\
\hline 17 & Isawo, Ikorodu LGA & $\mathrm{N}: 06^{\circ} 40^{\prime} 47.11^{\prime \prime}$ & E: $03^{\circ} 26^{\prime} 36.92^{\prime \prime}$ & 24.8 & 1541.81 & 20 \\
\hline 18 & Itamaga, Ikorodu LGA & $\mathrm{N}: 06^{\circ} 37^{\prime} 54.52^{\prime \prime}$ & E: $03^{\circ} 32^{\prime} 1.139^{\prime \prime}$ & 24.8 & 1541.81 & 18 \\
\hline 19 & Ibese, Ikorodu LGA & $\mathrm{N}: 06^{\circ} 35^{\prime} 11.19^{\prime \prime}$ & E: $03^{\circ} 29^{\prime} 15.76^{\prime \prime}$ & 24.8 & 1541.81 & 6 \\
\hline 20 & Isasi, Ikorodu LGA & $\mathrm{N}: 06^{\circ} 32^{\prime} 44.69^{\prime \prime}$ & E: $03^{\circ} 28^{\prime} 59.47^{\prime \prime}$ & 24.8 & 1541.81 & 5 \\
\hline 21 & Ofin, Ikorodu LGA & N: $06^{\circ} 33^{\prime} 35.15^{\prime \prime}$ & E: $03^{\circ} 31^{\prime} 28.56^{\prime \prime}$ & 24.8 & 1541.81 & 9 \\
\hline 22 & Oruba, Ikorodu LGA & $\mathrm{N}: 06^{\circ} 35^{\prime} 58.73^{\prime \prime}$ & E: $03^{\circ} 25^{\prime} 40.91^{\prime \prime}$ & 24.8 & 1541.81 & 8 \\
\hline 23 & Ebute, Ikorodu LGA & $\mathrm{N}: 06^{\circ} 36^{\prime} 47.311^{\prime \prime}$ & E: $03^{\circ} 28^{\prime} 13.89^{\prime \prime}$ & 24.8 & 1541.81 & 7 \\
\hline 24 & Owode, Kosofe LGA & $\mathrm{N}: 06^{\circ} 36^{\prime} 24.03^{\prime \prime}$ & E: $03^{\circ} 25^{\prime} 13.64^{\prime \prime}$ & 24.8 & 1541.81 & 9 \\
\hline 25 & Parafa, Kosofe LGA & N: $06^{\circ} 40^{\prime} 51.08^{\prime \prime}$ & E: $03^{\circ} 30^{\prime} 34.24^{\prime \prime}$ & 24.8 & 1541.81 & 15 \\
\hline 26 & Elesin, Ikorodu LGA & $\mathrm{N}: 06^{\circ} 40^{\prime} 8.086^{\prime \prime}$ & E: $03^{\circ} 32^{\prime} 17.15^{\prime \prime}$ & 24.8 & 1541.81 & 18 \\
\hline 27 & Oke Eletu, Ikorodu LGA & $\mathrm{N}: 06^{\circ} 39^{\prime} 16.664^{\prime \prime}$ & E: $03^{\circ} 30^{\prime} 16.03^{\prime \prime}$ & 24.8 & 1541.81 & 13 \\
\hline
\end{tabular}

Source: Nigeria Meteorological Agency (NIMET) station, Lagos.

Figure 2 shows the vertical distribution of SOC-Top soil $(0-10 \mathrm{~cm})$, Middle soil $(10-20 \mathrm{~cm})$ and Bottom soil $(20-30 \mathrm{~cm})$. SOC was highest in 8 top, 2 middle and 17 bottom soils.

In this study top soils were used to assess the influence of temperature, precipitation and altitude on SOC content. According to [12], the amount of SOC depends on soil texture, climate, vegetation and historical and current land use/management. The 8 locations with highest SOC in topsoil were locations 1 , $2,8,14,16,18,19$ and 23 with altitudes $8,0,14,7,10,18,6$ and 7 respectively. In the study on relation between SOC, climate and altitude, it was concluded by [18] that SOC generally decreases with increment of temperature and is positively correlated with annual precipitation and altitude. Our findings are in agreement with Wanhong's conclusion. As shown in Table 2, locations 1, 2, 3 \& 
Table 2. Topsoil SOC and $\mathrm{CO}_{2}$ emission at different sample locations.

\begin{tabular}{|c|c|c|c|c|c|c|c|c|}
\hline $\mathrm{S} / \mathrm{N}$ & $\begin{array}{l}\text { Sample } \\
\text { location }\end{array}$ & $\operatorname{MAT}\left({ }^{\circ} \mathrm{C}\right)$ & MAP (mm) & Altitude (m) & SOC $\mathrm{g} \mathrm{kg}^{-1}$ & $\mathrm{CO}_{2} \mathrm{~g} \cdot \mathrm{kg}^{-1}$ & $\begin{array}{c}\text { Soil texture } \\
\text { Clay/Silt/Sand }\end{array}$ & Vegetation type \\
\hline 1 & 1 & 27.9 & 1828.80 & 8 & 0.0095 & 0.0341 & $0.01 / 9.92 / 92.07$ & Built up Area/Grassland \\
\hline 2 & 2 & 27.9 & 1828.80 & 2 & 0.0040 & 0.0106 & $-/-/ 100$ & Grassland \\
\hline 3 & 8 & 27.9 & 1828.80 & 14 & 0.0121 & 0.0371 & $-/-/ 100$ & $\begin{array}{l}\text { Sand filled Area with } \\
\text { grown trees/Shrubs }\end{array}$ \\
\hline 4 & 14 & 25.2 & 1591.45 & 7 & 0.0070 & 0.0099 & $-/ 2.06 / 97.94$ & Forest \\
\hline 5 & 16 & 24.8 & 1541.81 & 10 & 0.0122 & 0.0171 & $-/ 3.77 / 96.23$ & Shrubs \\
\hline 6 & 18 & 24.8 & 1541.81 & 18 & 0.0084 & 0.0294 & $-/ 1.16 / 98.84$ & Forest \\
\hline 7 & 19 & 24.8 & 1541.81 & 6 & 0.0163 & 0.0555 & $-/ 24.01 / 89.12$ & Forest \\
\hline 8 & 23 & 24.8 & 1541.81 & 7 & 0.0176 & 0.0534 & $-/ 11.3 / 80.12$ & Forest \\
\hline
\end{tabular}

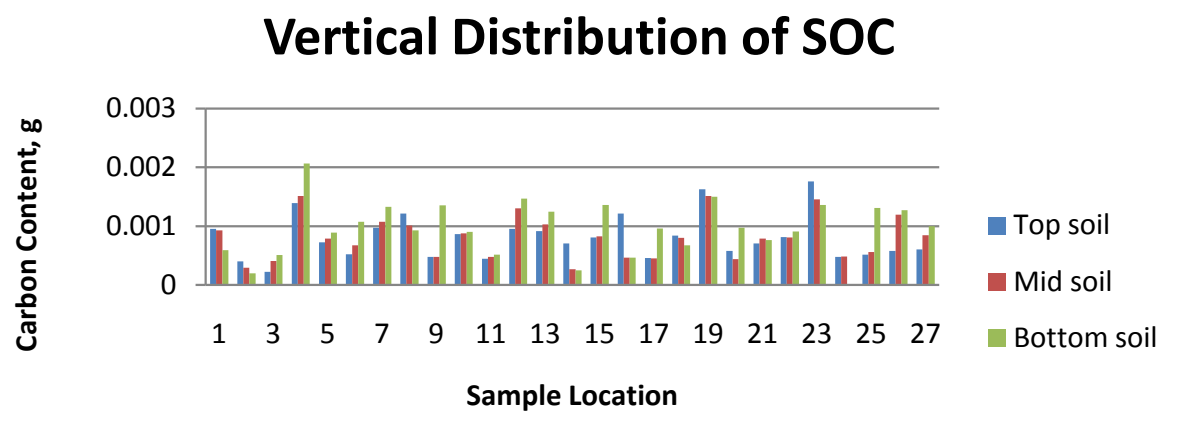

Figure 2. Distribution of SOC at different depths

4 with high temperature and high precipitation had low SOC. The SOC in location 3 is higher than the others within same temperature and precipitation because of the high altitude of $14 \mathrm{~m}$ and the vegetation type (a combination of trees and shrubs). Soils under natural forests or grassland tend to have higher SOC content [19] (Eleanor, 2009). Location 2 was observed to have the lowest SOC $\left(0.0040 \mathrm{~g} \cdot \mathrm{kg}^{-1}\right)$ of all locations because the altitude is lowest $(2 \mathrm{~m})$ there. Locations 16, 18, 19 and 23 had higher SOC contents due to low temperature, low precipitation and vegetation types (shrubs, forest, forest and forest respectively. For location 18 to have low temperature, low precipitation, high altitude and forest vegetation and yet had low SOC, it could be as a result of other factors such as historical and current land use/management. According to [12], the amount of SOC depends on soil texture, climate, vegetation and historical and current land use/management.

From Figure 2, 10 out of the 27 top soils $(0-10 \mathrm{~cm}), 2$ out of 27 middle soils $(10-20 \mathrm{~cm})$ and 17 of the $27(20-30 \mathrm{~cm})$ bottom soils had highest SOC contents. This result indicates that soil depth is one of the key factors that affect the SOC contents of the soil. It also indicates that SOC contents increase with depth. Our study is in agreement with [20] which estimated that the global stock of SOC is in the range $684-724 \mathrm{Pg}$ to a depth of $30 \mathrm{~cm}$ and $1462-1548 \mathrm{Pg}$ to a depth of $1 \mathrm{~m}$ [20]. As observed in Figure 3, soil depth ranging from 20 to $30 \mathrm{~cm}$ (bottom soil) had higher SOC contents than lower soil depths. Moisture content 
does not affect SOC of the soil as indicated by the varying moisture contents of soils at different depths and conditions in Table 3 in the supplementary data.

Clay was only found in 7 of the 81 soils in the following percentages: Location 1 topsoil $0.01 \%$, location 3 topsoil $2.94 \%$, location 17 bottom 5.07\%, location 25 bottom soil 7.25\%, location 26 middle and bottom soils $4.29 \%$ and $6.10 \%$ respectively, and location 27 bottom soil 3.19\%. Out of the 7 soil samples that had clay contents, 4 were bottom soils, 2 top soils and 1 middle soil. Comparing Figure 3 and Figure 4 revealed that Bottom soil had the highest SOC and clay contents, followed by the top soil while the middle soil had the least of the two (SOC and clay). Soil texture affects SOC because of the stabilizing properties that clay has on organic matter. Organic matter can be trapped in the very small spaces between clay particles making them inaccessible to micro-organisms and therefore slowing decomposition. In addition, clay offers chemical protection to organic matter through adsorption onto clay surfaces, which again prevents organic matter from being decomposed by bacteria. Soils with high clay content therefore tend to have higher SOC than soils with low clay content under similar land use and climate conditions [12].

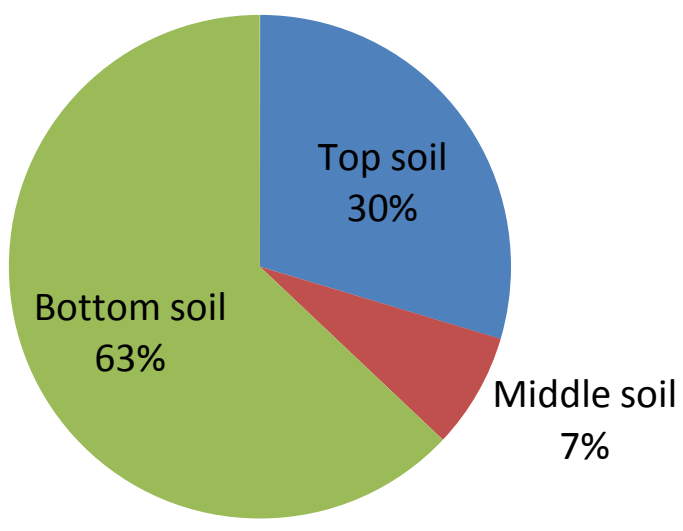

Figure 3. Distribution of SOC at different depth.

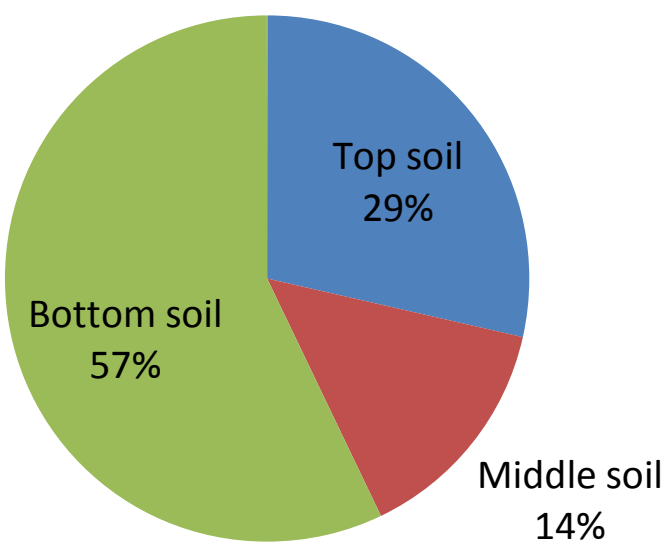

Figure 4. Percent distribution of Clay at different soil depths. 


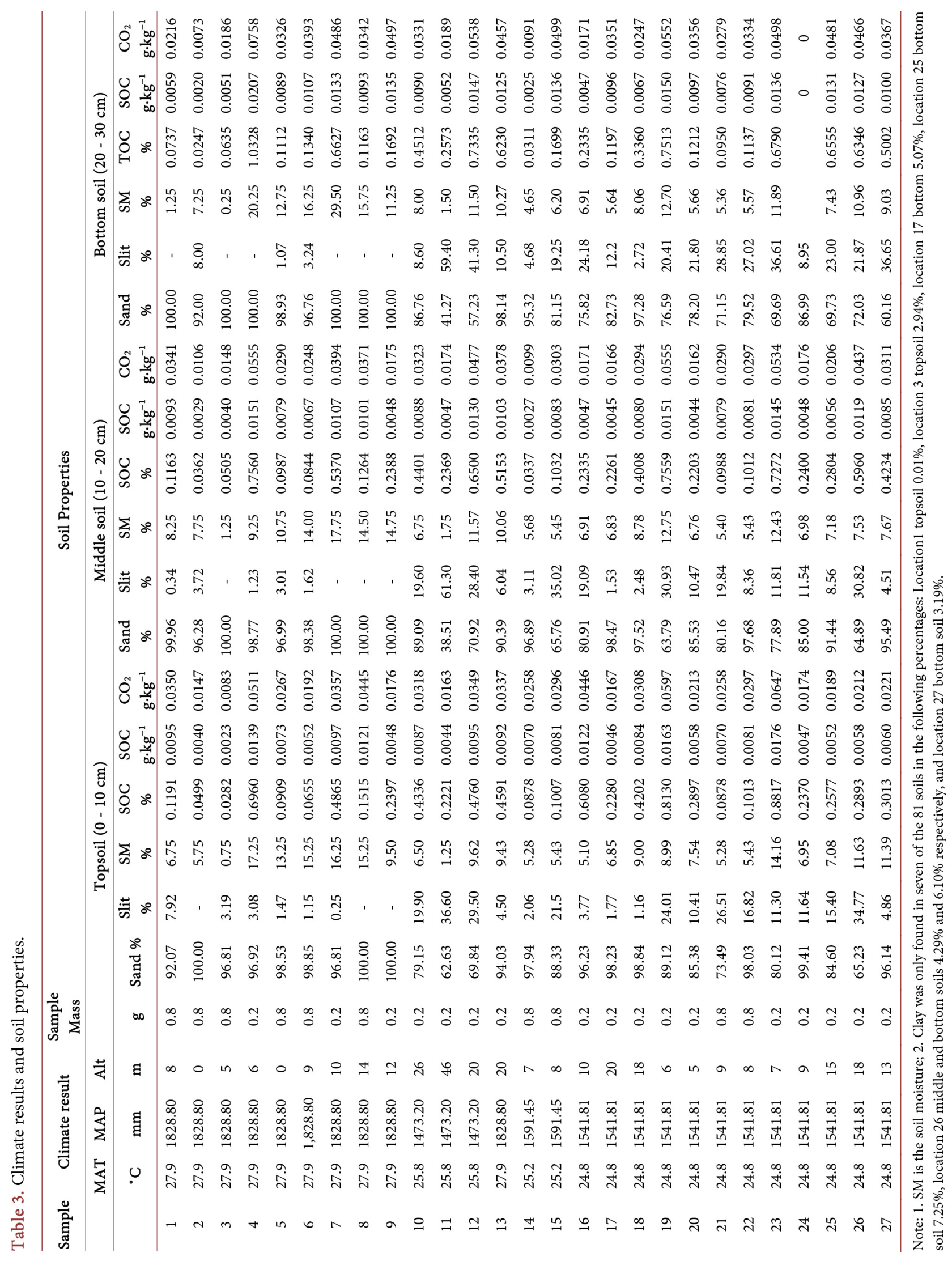


Locations 19, 23, 1, 3 and 18 were found to release more $\mathrm{CO}_{2}$ than other locations. This could be as a result of land use. According to [5] and [6], land use have contributed to a great increase in the amount of carbon dioxide $\left(\mathrm{CO}_{2}\right)$, atmospheric methane, carbon monoxide (CO) and other Green House Gases in the atmosphere. The high $\mathrm{CO}_{2}$ released could also be as a result of microbial activities. Microbial decomposition causes organic carbon to be mineralized and lost to the atmosphere as Carbon Dioxide $\left(\mathrm{CO}_{2}\right)$. Climate affects SOC amount as it is a major determinant of the rate of decomposition and therefore the turnover time of C in soils [12].

\section{Conclusion}

From our findings, it can be concluded that vegetation type, altitude, soil depth, soil texture, precipitation and temperature are key factors that affect SOC contents of the soil. Moisture content does not affect SOC content of the soil. Forests, shrubs and grassland enhance high SOC contents of the soil. SOC increases with increase in altitude. Clay soil texture enhances high SOC in soils. High temperature and precipitation reduce SOC contents of the soil. High temperature and altitude favour greenhouse gas emission from the soil. SOC and climate change are therefore greatly linked.

\section{Acknowledgements}

The authors wish to acknowledge the Department of Chemistry of the University of Lagos, Nigeria for providing the facilities used in this study.

\section{References}

[1] Schlesinger, W.H. (1997) Biogeochemistry. An Analysis of Global Change. 2nd Edition, Academic Press, San Diego, London, Boston, New York, Sydney, Tokyo, Toronto, $588 \mathrm{p}$.

[2] Raich, J.W. and Potter, C.S. (1995) Global Patterns of Carbon Dioxide Emissions from Soils. Global Biogeochemical Cycles, 9, 23-36. https://doi.org/10.1029/94GB02723

[3] Trumbore, S.E., Chadwick, O.A. and Amundson, R. (1996) Rapid Exchange between Soil Carbon and Atmospheric Carbon Dioxide Driven by Temperature Change. Science, 272, 393-396. https://doi.org/10.1126/science.272.5260.393

[4] Woodwell, G.M., Mackenzie, F.T., Houghton, R.A., Apps, M., Gorham, E. and Davidson, E. (1998) Biotic Feedbacks in the Warming of the Earth. Climatic Change, 40, 495-518. https://doi.org/10.1023/A:1005345429236

[5] Sims, P.L. and Bradford, J.A. (2001) Carbon Dioxide Fluxes in a Southern Plains Praire. Agricultural and Forest Meteorology, 109, 117-134. https://doi.org/10.1016/S0168-1923(01)00264-7

[6] Mickler, R.A. (2004) Natural Resource Management to Offset Greenhouse Gas Emissions-Preface. Environment Management, 33, 431-432.

https://doi.org/10.1007/s00267-003-9100-y

[7] IPCC (2001) Climate Change 2001: The Scientific Basis. Contribution of Working Group I to the Third Assessment Report of the Intergovernmental Panel on Climate Change. In: Houghton, J.T., Ding, Y., Griggs, D.J., Noguer, M., van der Linden, P.J., 
Dai, X., Maskell, K. and Johnson, C.A., Eds., Cambridge University Press, Cambridge, United Kingdom and New York, NY, USA, 881 p.

[8] Markham, A. (1996) Potential Impacts of Climate Change on Ecosystems: A Review of Implications for Policy Makers and Conservation Biologists. Climate Research, 6, 179-191. https://doi.org/10.3354/cr006179

[9] McCarty, J.P. (2001) Ecological Consequences of Recent Climate Change. Journal of the Society for Conservation Biology, 15, 320. https://doi.org/10.1046/j.1523-1739.2001.015002320.x

[10] Thomas, C.D., Cameron, A., Green, R.E., Bakkenes, M., Beaumont, L., Collingham, Y.C., Erasmus, B.F.N., Ferreira de Siqueira, M., Grainger, A., Hannah, L., Hughes, L., Huntley, B., van Jaarsveld, A.S., Midgley, G.F., Miles, L., Ortega-Huerta, M.A., Peterson, A.T., Phillips, O.L. and Williams, S.E. (2004) Extinction Risk from Climate Change. Nature, 427, 145-148. https://doi.org/10.1038/nature02121

[11] Iwugo, K.O., D’Arcy, B. and Andoh, R. (2003) Aspects of Land-Based Pollution of an African Coastal Megacity of Lagos. Diffuse Pollution Conference, Dublin, 14122.

[12] Liddicoat, C., Schapel, A., Davenport, D., et al. (2010) PIRSA Discussion Paper-Soil Carbon and Climate Change.

[13] Gifford, R.M., Cheney, N.P., Noble, J.C., Russell, J.S., Wellington, A.B. and Zammit, C. (1990) Australian Land Use, Primary Production of Vegetation and Carbon Pools in Relation to Atmospheric Carbon Dioxide Concentration. In: Gifford, R.M. and Barson, M.M., Eds., Australia's Renewable Resources. Sustainability and Global Change (Bureau of Rural Resources Proc 14) Canberra, Australian Government Publishing Service, Canberra, 151-188.

[14] Bellamy, P. (2010) Understanding the Driving Forces behind the Losses of Soil Carbon across England and Wales. Geophysical Research Abstract, 12, Article ID: 15029.

[15] Alvarez, R. and Lavado, R.S. (1998) Climate, Organic Matter and Clay Content Relationships in the Pampa and Chaco Soils, Argentina. Geoderma, 83, 127-141. https://doi.org/10.1016/S0016-7061(97)00141-9

[16] Chan, K.Y., Cowie, A., Kelly, G., Singh, B. and Slavich, P. (2008) Scoping Paper: Soil Organic Carbon Sequestration Potential for Agriculture. NSW, New South Wales Department of Primary Industries, Orange.

[17] Broos, K. and Baldock, J. (2008) Building Soil Carbon for Productivity and Implications for Carbon Accounting. 2008 South Australian GRDC Grains Research Update.

[18] Dai, W. and Huang, Y. (2005) Relation of Soil Organic Matter Concentration to Climate and Altitude in Zonal Soils of China. Catena, 65, 87-94.

[19] Eleanor Milne (2009) The Encyclopedia of Earth: Soil Organic Carbon.

[20] Batjes, N.H. (1996) Total Carbon and Nitrogen in the Soils of the World. European Journal of Soil Science, 47, 151-163.

https://doi.org/10.1111/j.1365-2389.1996.tb01386.x 
Submit or recommend next manuscript to SCIRP and we will provide best service for you:

Accepting pre-submission inquiries through Email, Facebook, LinkedIn, Twitter, etc. A wide selection of journals (inclusive of 9 subjects, more than 200 journals)

Providing 24-hour high-quality service

User-friendly online submission system

Fair and swift peer-review system

Efficient typesetting and proofreading procedure

Display of the result of downloads and visits, as well as the number of cited articles Maximum dissemination of your research work

Submit your manuscript at: http://papersubmission.scirp.org/

Or contact jep@scirp.org 